\title{
Conocimiento y opinión informada en la Pandemia SARS Covid-19
}

\author{
Mario Delgado-Noguera ${ }^{1}$
}

A través de la historia humana los principales problemas de salud que los hombres han enfrentado tienen que ver con la vida colectiva comunitaria (1). Para ilustrar esta afirmación viene al caso justamente lo que vivimos colectivamente con la pandemia por el COVID 19 SARS declarada por la OMS el 11 de marzo de 2020 (2). Al 4 de mayo de 2020 ya se contaban en el mundo más de 3 millones y medio de casos confirmados y 251.059 muertes (3).

La epidemiología puede ser considerada como una ciencia básica para la salud pública, pero también es fundamental, por su naturaleza de aplicar el método científico a los problemas de la salud, para apoyar con sus investigaciones comunitarias a las decisiones y acciones que tomen los politicos, de quienes depende el bienestar de la población (1). Este es el caso de la actual pandemia por el COVID 19 SARS. Sin embargo, es el momento para que aquellos demuestren interés por comprender una teoría científica y fortalecer el juicio para escoger la mejor entre varias alternativas con un sano e informado escepticismo, pues la historia demuestra que esta actitud es preferible en la ciencia y en este caso de la pandemia, para preferir la evidencia sobre la opinión y los intereses sesgados (1) por un interés particular.

Hay que tener en cuenta que algún hecho epidemiológico aplicado a la pandemia puede ser refutado y que las investigaciones y las teorías son dinámicas, pero es importante aceptar en estas circunstancias que las que se consideran como "verdades" pueden ser un asunto de opinión desde el poder. Tenemos el caso del presidente Donald Trump quien desde su "verdad", por ejemplo, ha quitado el apoyo económico a la OMS y de paso a su filial regional, la OPS, justo cuando más se necesitaba a este organismo que vela por la salud global para avanzar en el conocimiento, insuficiente e impreciso, de la pandemia y su agente causal (4). Un voz como la del presidente de Estados Unidos tiene una gran resonancia planetaria y muchos creenán que la OMS no informó adecuada ni oportunamente el peligro que representaba el virus.

1 Universidad del Cauca. Editor general de publicaciones. Sello editorial. Popayán, Colombia. 
Por otraparte, las opiniones se expanden por internetmasivamente y las evidencias desde el conocimiento científico tambien son asequibles por la web, pero, en medio de la avalancha informativa, llegan de manera limitada a su público restringido. No es sospresivo entonces que el personal de salud, que se dedica a la investigación de campo y a la salud comunitaria, deba por un lado informar y por otro entrar al debate para diferenciar la opinión y la evidencia (5). En una mayoría, los médicos y el personal de salud no han sido formados para escribir y debatir en los medios; se han dedicado preferentemente a la atención de lospacientes.

El virus SARS-Covid-19, de la familia de los Coronavirus, es un virus exitoso en su diseminación (6). Según David Quammen, un divulgador científico, la pandemia no era sorpresiva, era más bien predecible pero los Gobiernos no se molestaron en prepararse (7). Es un caso semejante al cambio climático. Como especie, los humanos somos responsables de estas situaciones. A partir de esta pandemia, es más urgente que nuestros hábitos de consumo y de vida se replanteen.

El conocimiento sólido y preciso es importante entonces a la hora de separar la opinión sesgada y las fake news. Son los hechos y su cuantificación e interpretación sin sesgos, los que ahora se sitúan más allá de la opinión privada basada en el poder y la oportunidad de ampliar suspropios intereses. Esta información es generalmente contrastada y verificada; por lo tanto, se debe apoyar a los epidemiólogos que trabajan desde las instituciones y al personal de salud hospitalario, quienes viven en carne propia el estrés de la pandemia (8).

\section{REFERENCIAS}

1. Shoemaker R, Delgado-Noguera M. Fundamentos de Epidemiología Vol 1. Popayán: Editorial Universidad del Cauca; 2019. 204 p.

2. Organización Mundial de la Salud (OMS). Alocución de apertura del Director General de la OMS en la rueda de prensa sobre la COVID-19 celebrada el 11 de marzo de 2020 [Internet]. [Consultado 15 marzo 2020] Disponible en: https://www.who.int/es/dg/speeches/detail/ who-director-general-s-opening-remarks-at-the-media-briefing-on-covid-19--11-march-2020

3. World Health Organization (WHO) Coronavirus disease (COVID-19) Pandemic [Internet]. [Consultado 15 marzo 2020]. Disponible en: https://www.who.int/emergencies/diseases/ novel-coronavirus-2019

4. Trump ends US aid to WHO, says not enough done to stop virus. The Washington Post (EEUU). [Internet]. 14 de abril del 2020; Disponible en: https://www.washingtonpost. com/politics/trump-directs-halt-to-payments-to-who-during-virus-pandemic/2020/04/14/ f4ae2024-7eb2-11ea-84c2-0792d8591911_story.html

5. Klimek M. "Scientific truth" in modern times: some considerations. Colombian Journal of Anesthesiology. 2020;48(2):59-60. DOI: 10.1097/CJ9.0000000000000145

6. Perlman S. Another Decade, Another Coronavirus. New England Journal of Medicine. 2020;382(8):760-2. DOI: 10.1056/NEJMe2001126

7. Marc Bassets. "Somos más abundantes que cualquier otro gran animal. En algún momento habrá una corrección" Quammen D. El Pais (Espańa). [Internet]. 18 de abril del 2020. Disponible en: https://elpais.com/ciencia/2020-04-18/somos-mas-abundantes-quecualquier-otro-gran-animal-en-algun-momento-habra-una-correccion.html

8. Muńoz Molina A. El regreso del conocimiento. El Pais (Espańa). [Internet]. 24 de marzo del 2020. Disponible en: https://elpais.com/elpais/2020/03/24/opinion/1585071202_661178.html 


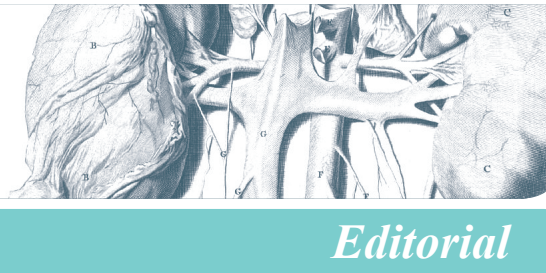

\title{
Knowledge and informed opinion in the SARS Covid-19 Pandemic
}

\author{
Mario Delgado-Noguera ${ }^{1}$
}

Throughout human history, the main health problems that men have faced have relation with collective community life (1). To illustrate this statement, that is exactly what we live with the COVID 19 SARS declared pandemic by the WHO on March 11, 2020 (2). As of May 4, 2020, there were already more than 3.5 million confirmed cases worldwide and 251,059 deaths (3).

Epidemiology can be considered as a basic science for public health, but it is also crucial by its nature to apply the scientific method to health problems and supporting with its results the decisions and actions taken by the politicians of who depends on the welfare of the population (1). This is the case of the current pandemic by COVID 19 SARS. However, it is time for those to show interest in understanding a scientific theory and strengthening the judgment to choose the best among several alternatives with a healthy and informed skepticism. History shows that this attitude is preferable in science than to prefer a biased interest (1) by a particular importance.

It must be considered that some epidemiological facts applied to the pandemic can be refuted and theories are dynamic. It is important to accept in these circumstances that what are considering "truths" may be a matter of opinion from the power. We have the case of President Donald Trump who, from his "truth", for example, has withdrawn financial support for the WHO and, incidentally, his regional subsidiary, PAHO, just when this organization that watches over global health was most needed to advance in the insufficient and imprecise knowledge of the pandemic and its causal agent (4). A voice like that, the President of United States, has a great planetary resonance and many will believe that the WHO did not adequately or timely report the danger posed by the virus.

On the other hand, opinions are expanding on the Internet massively and the evidence from scientific knowledge is also available on the web, but, in the midst of the big amount of information, they reach their restricted audience in a limited way. It is not surprising, then, that health personnel who are dedicated to research and community health, should inform

1 Universidad del Cauca. Editor general de publicaciones. Sello editorial. Popayán, Colombia. 
and also, enter the debate to differentiate opinion and evidence (5). In a majority, doctors and health personnel have not been trained to write and debate with the media in the midst of patient care.

The SARS-Covid-19 virus, of the Coronavirus family, is a successful virus in its spread (6). According to David Quammen, a scientific divulgator, the pandemic was not surprising, it was rather predictable but governments did not bother to prepare (7). It is a case similar to climate change. As a species, humans are responsible for these situations. After this pandemic, it is more urgent that our consumption and life habits must be reconsidered.

Solid and accurate knowledge is very important when separating biased opinion and fake news. It is the facts and their interpretation that now lie beyond private opinion based on power and the opportunity to broaden their own interests. This information is generally contrasted and verified. Therefore, epidemiologists working from the institutions, and hospital health personnel who live in the first line the stress of the pandemic, should be strongly supported (8).

\section{REFERENCES}

1. Shoemaker R, Delgado-Noguera M. Fundamentos de Epidemiología Vol 1. Popayán: Editorial Universidad del Cauca; 2019. $204 \mathrm{p}$.

2. Organización Mundial de la Salud (OMS). Alocución de apertura del Director General de la OMS en la rueda de prensa sobre la COVID-19 celebrada el 11 de marzo de 2020 [Internet]. [Consultado 15 marzo 2020] Disponible en: https://www.who.int/es/dg/speeches/detail/ who-director-general-s-opening-remarks-at-the-media-briefing-on-covid-19-11-march-2020

3. World Health Organization (WHO) Coronavirus disease (COVID-19) Pandemic [Internet]. [Consultado 15 marzo 2020]. Disponible en: https://www.who.int/emergencies/diseases/ novel-coronavirus-2019

4. Trump ends US aid to WHO, says not enough done to stop virus. The Washington Post (EEUU). [Internet]. 14 de abril del 2020; Disponible en: https://www.washingtonpost. com/politics/trump-directs-halt-to-payments-to-who-during-virus-pandemic/2020/04/14/ f4ae2024-7eb2-11ea-84c2-0792d8591911_story.html

5. Klimek M. "Scientific truth" in modern times: some considerations. Colombian Journal of Anesthesiology. 2020;48(2):59-60. DOI: 10.1097/CJ9.0000000000000145

6. Perlman S. Another Decade, Another Coronavirus. New England Journal of Medicine. 2020;382(8):760-2. DOI: 10.1056/NEJMe2001126

7. Marc Bassets. "Somos más abundantes que cualquier otro gran animal. En algún momento habrá una corrección" Quammen D. El Pais (Espańa). [Internet]. 18 de abril del 2020. Disponible en: https://elpais.com/ciencia/2020-04-18/somos-mas-abundantes-que-cualquierotro-gran-animal-en-algun-momento-habra-una-correccion.html

8. Muńoz Molina A. El regreso del conocimiento. El Pais (Espańa). [Internet]. 24 de marzo del 2020. Disponible en: https://elpais.com/elpais/2020/03/24/opinion/1585071202_661178.html 